\title{
DEAD WOOD, FOREST FRAGMENTATION AND ELEVATION INFLUENCES MACROFUNGAL DIVERSITY ON DOWNED COARSE WOODY DEBRIS IN BEECH AND OAK OLD FOREST ECOSYSTEMS FROM NORTHEASTERN ROMANIA
}

\author{
Ovidiu COPOT $^{1 *}$, Cătălin TĂNASE ${ }^{2}$ \\ 1 “Alexandru Ioan Cuza” University of Iaşi, “Anastasie Fătu” Botanical Garden, Dumbrava Roşie \\ Street no. 7-9, 700487 Iaşi - Romania \\ ${ }^{2}$ Department of Biology, Faculty of Biology, "Alexandru Ioan Cuza” University of Iaşi, 20A Carol I, \\ 700505, Iaşi - Romania \\ *Corresponding author. E-mail: ovidiu.copot@uaic.ro
}

\begin{abstract}
Coarse woody debris is often highlighted as the most important microhabitat for numerous saproxylic species, including macrofungi. Providing valuable nutrients, stable microclimatic conditions and development space, $\log$ s and large branches are considered of great ecological value for macrofungal diversity conservation. Old forests are especially rich in downed coarse dead wood both at quantity and quality level. Unfortunately, these forests are also affected by human interventions, through wood extraction and forest fragmentation. The main objective of this study was to find the factors that best explain the macrofungal diversity on downed coarse woody debris (DCWD). For this, we sampled 21 plots in forests dominated by beech or oak from Northeastern Romania, where we collected data about fungi, forest structure, and dead wood. We completed the variables set with forest fragmentation and topographic indices. In order to find the best models and predictors, we used generalized linear models (GLM). We found 163 taxa, polypores and agarics being the most frequent. The two most important predictors had a positive effect, increasing macrofungal diversity: 2'nd and 3'rd decay stages DCWD volume and elevation while the third one had a hump-shape effect on diversity. In old forests, downed dead wood quality and quantity is a vital component for numerous species of fungi to survive and develop. Elevation is a known proxy of macroclimatic conditions, furthermore creating new richresources niches because increasing humidity and taxonomic diversification by conifers occurrence. Patch shape can have divergent effects on fungi, as increasing perimeter is associated from one point on, with human deforestation and accessibility. Overall, we believe that Northeastern Romania's old forests hosts a great lignicolous macrofungal richness, which will be protected through silvicultural practices such as keeping valuable dead wood on site.
\end{abstract}

Keywords: broadleaved dominated forest, forest structure, lignicolous fungal richness, logs and large branches, shape index, topography.

\section{Introduction}

Coarse woody debris (CWD) is one of the most important types of microhabitats found in forest ecosystems [HEILMANN-CLAUSEN \& CHRISTENSEN, 2003]. Numerous groups of organisms depend on food and/or shelter provided by this type of wood, including lichens, bryophytes, insects and fungi [ABREGO \& SALCEDO, 2011; GOIA \& GAFTA, 2018; HEILMANN-CLAUSEN \& CHRISTENSEN, 2003].

The most important forest types characterized by high dead wood volume and highdecay wood volume are the old forests [MORRISSEY \& al. 2014]. Numerous studies carried out in these forests across the Northern hemisphere highlighted the importance of those habitats for lignicolous fungal high diversity conservation [RUOKOLAINEN \& al. 2018; 
RUNNEL \& LÕHMUS, 2017; SAAR \& al. 2007]. Furthermore, this importance was sustained by studies comparing natural/old-growth forests with managed ones, silvicultural practices usually changing lignicolous fungal composition and reducing diversity [ABREGO \& al. 2014; JUUTILAINEN \& al. 2014; KEBLI \& al. 2012]. Unfortunately, old forests take a long time to develop, period during which human intervention should be restricted and driven by special conservative measures focused on retaining large dead wood (including both DCWD and dead trees) and large living trees [SIITONEN \& al. 2000].

Dead wood characteristics were studied in lignicolous fungal diversity or composition-related researches in forest habitats, either at plot-level: volume, dead wood species diversity [RUNNEL \& LÕHMUS, 2017] or substrate-level: species, diameter, decay class, bark cover, moss cover, age, complexity, microclimatic conditions [HEILMANNCLAUSEN, 2001; HEILMANN-CLAUSEN \& CHRISTENSEN, 2003; HEILMANNCLAUSEN \& al. 2005; HEILMANN-CLAUSEN \& al. 2014; ABREGO \& al. 2017; RUOKOLAINEN \& al. 2018]. Different forest characteristics have been studied in relation to fungal diversity and composition of lignicolous fungi in Europe: tree richness, relative volume of dominant, codominant or non-dominant trees [KUTSEGI \& al. 2015]; or structure: tree density, large tree density, tree basal area, mean tree DBH, tree DBH coefficient of variation, snags volume, cover of understorey vegetation [KUTSEGI \& al. 2015]. Also, forest fragmentation was included in lignicolous fungal-related studies, using characteristics such as forest area, broadleaved or coniferous forest area [RUNNEL \& LÖHMUS, 2017], forest connectivity at different spatial scales, reserve size [ABREGO \& al. 2015].

This study tries to respond to the following questions: i) does forest structure influence lignicolous fungal diversity? ii) is the forest fragmentation important in beech/oak old forests from Northeastern Romania for wood-inhabiting fungi? iii) does dead wood high quality and quantity increases the number of lignicolous fungal species?

\section{Material and methods}

\section{Study area}

The study was conducted in beech- and oak-dominated forests from Northeastern Romania (Figure 1). These forests are situated in the Moldavian Plateau, Sub-Carpathians Hills and the Eastern part of Eastern Carpathians. The main soils are cambisoils and luvisoils. The climate is temperate continental, with an increasing continentality towards the easternmost located studied forests. The studied forests are dominated either by Fagus sylvatica L. (European beech) or species of Quercus (oak), ones of the most important tree genera in Europe [PETRITAN \& al. 2012] and Romania [MILESCU \& al. 1967]. Region's forests are prone to deforestation and illegal logging [ANDRONACHE \& al. 2017]. Also, even if there measures for old-growth forests protection were taken, logging, invasive species, and climate change are still important threats [KNORN \& al. 2012].

\section{Datasets}

In beech and oak forests we chose circular plots of 1,000 $\mathrm{m}$ for forest and dead wood data inventory. The plots were chosen using the $50 \%$ threshold in terms of tree basal area of beech/oak from the total basal area. Each plot had at least one big branch or log (diameter at larger end $>10 \mathrm{~cm}$ ). Within each plot, all living and dead trees with a diameter at breast height $(\mathrm{DBH})>10 \mathrm{~cm}$ were measured for diameter. Old or large-sized trees were considered those trees with DBH $>50 \mathrm{~cm}$ [LOMBARDI \& al. 2012]. For old-forests delineation, we 
chose only plots in which old trees basal area proportion was at least $50 \%$ of the total tree basal area.

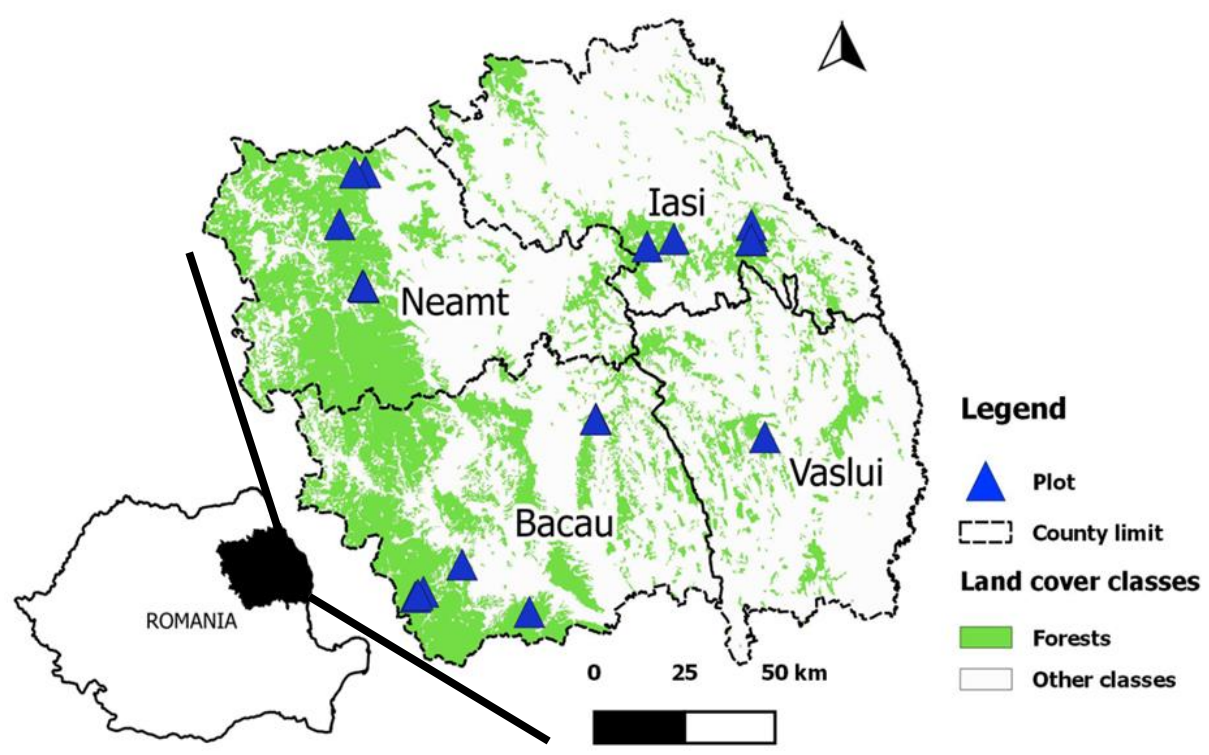

Figure 1. Plots location in Northeastern Romania

In each plot, we measured all logs and large branches with the diameter at large end $>10 \mathrm{~cm}$, the diameter of both ends, length and decay stage using 3 classes. The decay classes are an adaptation of the classification proposed by HEILMANN-CLAUSEN \& CHRISTENSEN (2003): (i) incipient stage - intact bark, twigs presence, hard texture, original color of wood, the knife penetrates less than $1 \mathrm{~cm}$ into the wood; (ii) intermediary stage - absent bark, absent twigs, hard and soft texture, changed wood color, the knife penetrates up to $6 \mathrm{~cm}$ into the wood; (iii) advanced stage: absent bark, absent twigs, completely change wood color, wood crashes in hand when humid, the knife penetrates fully into the wood.

For each plot, forest structure-specific variables were assessed (Table 1): tree richness, tree density, young tree density, tree basal area, tree diameter coefficient of variation, snags basal area, snags density, beech basal area proportion, and oak basal area proportion.

Dead wood characteristics were also calculated (Table 1): DCWD volume, DCWD taxonomic diversity, DCWD decay diversity, DCWD volume in middle and late decay stages. DCWD volume was calculated using frustum of cone formula. DCWD decay and taxonomic diversity were calculated following RUNNEL \& LÕHMUS (2017).

Forest fragmentation was based on Corine Land Cover 2018 raster with $100 \mathrm{~m}$ resolution (https://land.copernicus.eu). The classes were reclassified such that CLC forest classes were grouped in 'forest class' and the others in 'other classes'. In circular areas of 2,000 
$\mathrm{m}$ radius having in the center the forest plot, we calculated indices at class level: patch area mean index and edge density index, or at patch level: shape index.

Main topographic variables were obtained for each plot: slope, positive openness, aspect index, and elevation. The derived topographic indices were calculated based on SRTM at $30 \mathrm{~m}$ resolution, downloaded from the official database of United States Geological Survey's EarthExplorer [www.earthexplorer.usgs.gov].

Table 1. Variables considered in the analysis

\begin{tabular}{|c|c|c|c|c|c|}
\hline Abbreviation & Name & Range & Mean & Units & GLM \\
\hline \multicolumn{6}{|l|}{ Forest structure } \\
\hline TREE_RICH & tree richness & $1-7$ & 4 & None & 1 \\
\hline TREE_N & tree density & $160-410$ & 285 & trees $\mathrm{ha}^{-1}$ & 0 \\
\hline TREE_U50_N & young tree density & $50-320$ & 190 & trees ha $^{-1}$ & 1 \\
\hline TREE_DBH_CV & $\begin{array}{l}\text { tree diameter coefficient } \\
\text { of variation }\end{array}$ & $0.4-1.9$ & 0.9 & None & 1 \\
\hline TREE_BA & tree basal area & $22.7-68.2$ & 50.5 & $\mathrm{~m}^{2}$ & 1 \\
\hline TREE_BA_MN & mean tree basal area & $0.1-0.3$ & 0.2 & $\mathrm{~m}^{2}$ & 0 \\
\hline SNAG_BA & snags basal area & $0-14.2$ & 0.6 & $\mathrm{~m}^{2} \mathrm{ha}^{-1}$ & 1 \\
\hline SNAG_N & snag density & $0-60$ & 10 & snags ha ${ }^{-1}$ & 1 \\
\hline BEECH & $\begin{array}{l}\text { beech trees basal area } \\
\text { proportion }\end{array}$ & $0-100$ & 51.7 & $\%$ & 0 \\
\hline OAK & $\begin{array}{l}\text { oak trees basal area } \\
\text { proportion }\end{array}$ & $0-82.1$ & 7.2 & $\%$ & 0 \\
\hline \multicolumn{6}{|c|}{ Downed dead wood } \\
\hline DCWD_DIV & $\begin{array}{l}\text { DCWD taxonomic } \\
\text { diversity }\end{array}$ & $0-0.9$ & 0.2 & None & 1 \\
\hline DCWD_DECAY & DCWD decay diversity & $0-0.9$ & 0.6 & None & 1 \\
\hline DCWD_VOL & DCWD volume & $0.1-148.8$ & 2.8 & $\mathrm{~m}^{3}$ & 1 \\
\hline DCWD_VOL23 & $\begin{array}{l}\text { DCWD volume in 2'nd } \\
\text { and 3'rd decay stages }\end{array}$ & $0-68.1$ & 1.1 & $\mathrm{~m}^{3}$ & 1 \\
\hline \multicolumn{6}{|c|}{ Forest fragmentation } \\
\hline AREA_MN & mean of patch area index & $54.6-1600.0$ & 388.7 & ha & 1 \\
\hline SHAPE & shape index & $5.9-33.4$ & 15.6 & None & 1 \\
\hline $\mathrm{ED}$ & edge density index & $0-23.3$ & 13.5 & $\mathrm{~m} \mathrm{ha}^{-1}$ & 0 \\
\hline \multicolumn{6}{|l|}{ Topography } \\
\hline ALT & elevation & $186-706$ & 450 & $\mathrm{~m}$ & 1 \\
\hline SLOPE & slope & $0.7-30.4$ & 7.7 & $\circ$ & 0 \\
\hline ASPI & aspect index & $6.7-156.0$ & 56.3 & $\circ$ & 1 \\
\hline $\mathrm{PO}$ & positive openness index & $1.2-1.5$ & 1.4 & None & 1 \\
\hline
\end{tabular}


In a concentric plot of $2,000 \mathrm{~m}^{2}$, each macrofungal species found on downed coarse woody debris was identified at species or genera level. Those which couldn't be determined in situ were identified in the laboratory using mycological literature [BERNICCHIA, 2005; BREITENBACH \& KRÄNZLIN, 1986; COURTECUISSE \& DUHEM, 2013; GERHARDT, 1999; RYVARDEN, 1991; SĂLĂGEANU \& SĂLĂGEANU, 1985; TĂNASE $\&$ al. 2009]. Index Fungorum [http://www.indexfungorum.org/Names/Names.asp] was used for fungal nomenclature.

\section{Data and analysis}

We used R software version 3.5.1 (R Core Team 2012) in data exploration and statistical analysis. The R packages used were: landscapemetrics, MuMIn, MASS, reshape, rsq. Packages ggplot2 and RColorBrewer were used for graphical representation of relationships. For topographical and CLC processing, we used QGIS [QGIS Development Team (2018). QGIS Geographic Information System. Open Source Geospatial Foundation Project. http://qgis.osgeo.org] and SAGA GIS software [CONRAD \& al. 2015].

We tested the 20 variables for collinearity with Pearson correlation and removed the variables from collinear pairs so that only one remained using the correlation coefficient threshold of 0.7. Using 15 non-correlated variables, we made GLM (Generalised Linear Models) with Poisson probability distribution and tested them for overdispersion. The resulted models were selected based on AIKc (Akaike Information Criterion corrected) value, using the method proposed by BURHNHAM \& ANDERSON (2002). These models were used to select the most important variables that explained the lignicolous macrofungal diversity.

\section{Results and discussions}

\section{Taxonomic diversity}

We found 163 species in approximately 500 records, on 249 logs and large branches. The diversity was higher than other studies made in similar habitats - 44 [BÎRSAN \& al. 2014], 72 [ŽUPANIC \& al. 2009]. In a study made in beech forests in the same region, the authors [COPOȚ \& al. 2018] found 110 species, but they only gathered data from fine woody debris (FWD), with diameter less than $10 \mathrm{~cm}$. In similar studies, like those from Danish deciduous forests, the authors [HEILMANN-CLAUSEN, 2001; HEILMANN-CLAUSEN \& CHRISTENSEN, 2003] found a higher number of species on beech logs. Still, the logs had more than $70 \mathrm{~cm}$ in diameter and consequently, the higher richness could be explained, besides other factors, by the log diameter, as it is known that diameter and associated-big log characteristics (e.g. better microclimate for mycelial development) is highly associated with lignicolous fungal diversity [HEILMANN-CLAUSEN \& CHRISTENSEN, 2003].

The species belong to 113 genera, of which Mycena and Pluteus were the richest. The majority of the species (159) belongs to 58 families (4 species were included in Incertae Sedis), from which the most important in diversity were: Polyporaceae and Mycenaceae, each of them with 15 taxa. 162 species belong to 22 orders and one to Incertae Sedis, from which Agaricales (36.2\% of total), Polyporales (19.0\%), Xylariales (8.5\%) and Hymenochaetales (7.3\%) where the richest. Basidiomycota phylum comprises $79.1 \%$ of total diversity, while Ascomycota, $20.9 \%$.

Half of the species (88) were identified in a single plot and another 24 in two plots. The most frequent found taxa in terms of plots presences were: (a) saproparasites: Fomes fomentarius, Fomitopsis pinicola; (b) saprotrophes of first decay stages: Jackrogersella 
cohaerens, Schizophyllum commune, Stereum hirsutum, Trametes versicolor; or (c) middle and late decay stages: Chlorociboria sp., Mollisia sp., Orbilia sp., Scutellinia scutellata, Pluteus cervinus. Those species were also frequently found growing on logs, especially beech [ABREGO \& SALCEDO, 2011; HEILMANN-CLAUSEN, 2001], but can also grow on other tree genera [BREITENBACH \& KRÄNZLIN, 1986; TĂNASE \& al. 2009]. Among the most frequently found species on fresh dead wood, F. fomentarius is a common sight on stem/large branches, of living, dying or fallen trees [BAUM \& al. 2003], as it is one of the main decay fungi of beech [SCHWARZE, 1994].

\section{Models that explain macrofungal diversity on DCWD}

Following model selection, we obtained two models that best explain the macrofungal diversity on downed coarse woody debris in beech or oak-dominated forests (Table 2).

Table 2. Best explaining models of macrofungal diversity found on downed coarse woody debris in beech or oak-dominated forests

\begin{tabular}{|c|c|c|c|c|c|c|c|c|c|}
\hline Intercept & ALT & DCWD_VOL & DCWD_VOL23 & SHAPE & $\mathbf{R}^{\mathbf{2}}$ & $\begin{array}{c}\mathbf{R}^{\mathbf{2}} \\
\text { adj. }\end{array}$ & AICc & delta & weight \\
\hline 1.784 & 0.003 & - & 0.015 & -0.031 & 0.99 & 0.99 & 140.04 & 0 & 0.67 \\
\hline 1.775 & 0.003 & 0.003 & 0.012 & -0.036 & 0.99 & 0.99 & 141.48 & 1.44 & 0.33 \\
\hline
\end{tabular}

The variables found important were: SHAPE (Shape Index), DCWD_VOL_D23 (DCWD volume in 2'nd and 3'rd decay stages) and ALT (elevation), (Table 3). Together, they explained $76 \%$ of the fungal richness variation.

Table 3. Linear models highlighting effect of the most important variables on macrofungal richness

\begin{tabular}{|l|c|c|c|c|c|c|}
\hline \multicolumn{1}{|c|}{ Variable } & Estimate & $\begin{array}{c}\text { Standard } \\
\text { Error }\end{array}$ & $\begin{array}{c}\text { Explains } \\
(\boldsymbol{\%})\end{array}$ & $\begin{array}{c}\mathbf{p} \text {-value } \\
(<\mathbf{0 . 0 5})\end{array}$ & Sign & Importance \\
\hline Elevation & 0.032 & 0.014 & 17 & $<0.05$ & $\uparrow$ & 0.90 \\
\hline $\begin{array}{l}\text { 2'nd and 3'rd decay DCWD } \\
\text { volume }\end{array}$ & 0.484 & 0.121 & 42 & $<0.001$ & $\uparrow$ & 0.63 \\
\hline Shape Index & $\begin{array}{c}5.713 \\
-0.137\end{array}$ & $\begin{array}{c}1.227 \\
0.028\end{array}$ & 50 & $\begin{array}{c}<0.0005 \\
<0.0005\end{array}$ & $\cap$ & 0.62 \\
\hline
\end{tabular}

\section{Predictors that influence macrofungal diversity on DCWD Elevation}

In this study, as the elevation is increasing, the macrofungal richness is higher (Figure 2.A). The elevation is considered as a proxy for macroclimatic conditions, especially mean annual precipitations and mean annual temperatures [VAN GILS \& al. 2012]. As a consequence, it is possible that the high richness associated with higher altitudes is in fact an effect of precipitations and temperature regimes. Indeed, the plots associated with higher diversity are found in mountainous forests, at elevations above $600 \mathrm{~m}$. Because of the mountain encampment, higher precipitations and lower temperatures create more humid conditions in the forests, which enhance and keep for long periods of time, the deadwood humidity. This can be a decisive factor, especially in carpophore-based studies, when fungi produce a large amount of carpophores during rich-pluvial seasons [BRAZEE \& al. 2014; RUDOLPH \& al. 2018]. Linked to the next found predictor is the fact that in temperate forests, the regions with colder summers (like mountains) are associated with higher dead 
wood quantities [WOODALL \& LIKNES, 2008]. Thus, the higher elevation plots can host a higher lignicolous macrofungal richness due to higher dead wood volumes.

A

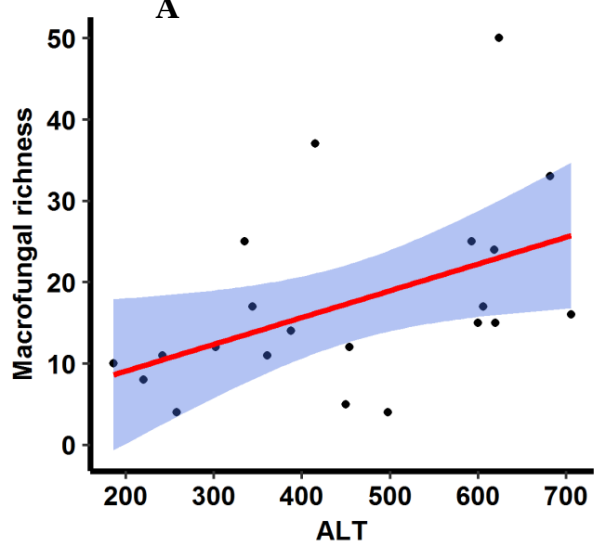

B

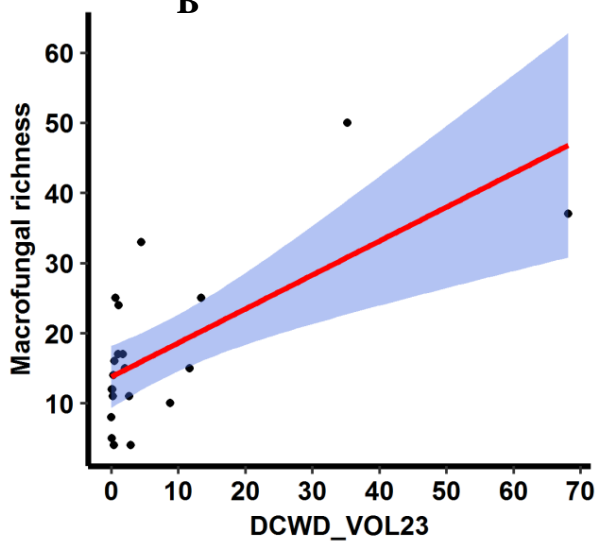

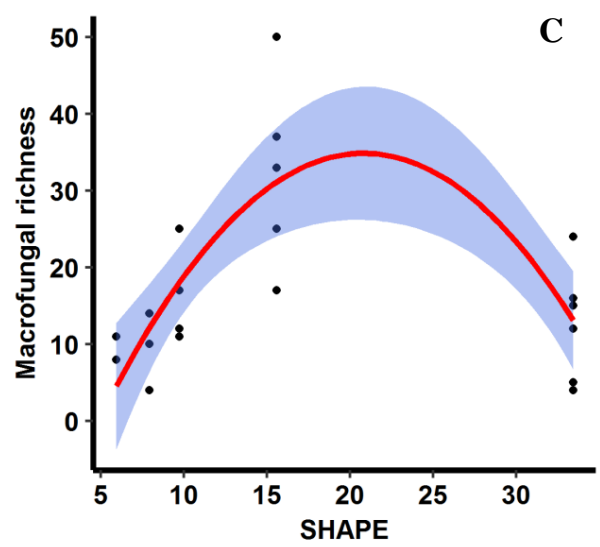

Figure 2. Relationship between macrofungal diversity and the most important variables: A. elevation (m); B. 2'nd and 3'rd decay stage of downed coarse woody debris $\left(\mathrm{m}^{3}\right)$; C. Shape Index

Another effect of elevation on forest plots composition differentiation is the occurrence of conifers in Romanian forests. Thus, at higher altitudes, the presence of coniferous dead wood creates important ecological niches which do not exist in forests dominated by pedunculate oaks (Quercus robur), like in Moldavian Plateau. Those niches are colonized both by some broadleaved-associated fungi and especially by coniferousspecific fungi, thus increasing total diversity on DCWD. 


\section{Middle and late stage decayed DCWD volume}

In our study, the DCWD volume in the middle and last decay stages was positively and significantly influencing the macrofungal diversity (Figure 2.B). This variable was calculated taking into account two assumptions: (i) one of the main old-growth forests characteristics is the presence of dead wood in large volumes [BRUNET \& al. 2010; DVOŘÁK \& al. 2017]; the main reason behind this is represented by the protective status of those forests, as silvicultural measures tend to keep dead trees on-site [ÇOLAK \& al. 2010] - the source of downed dead wood [DOMKE \& al. 2013]; thus, the presence of large quantities of middle and late decayed wood is a measure of continuous forest protection; pro-conservative forest management proved to positively influence lignicolous fungal diversity in old-growth hardwood forests [BRAZEE \& al. 2014]; (ii) middle and last decay stage of wood hosts a diverse variety of macrofungi, many of them decay-stage specialists [HEILMANNCLAUSEN \& CHRISTENSEN, 2003; HEILMANN-CLAUSEN \& al. 2014].

Here, this volume alone explains approximately $40 \%$ of total macrofungal richness. The species-richest plots are found in Nemira mountains (Eastern Carpathians, Bacău county), in a beech-silver fir forest. This habitat is rich in downed deadwood of both beech and coniferous trees, thus completing the previous predictor explanation.

\section{Shape Index}

In our study, the macrofungal richness follows a hump-shaped relationship with the Shape Index (Table 2). Initially, as the index is increasing, so is the diversity, until it approaches a mid-value of approximately 20, after which the diversity is decreasing as the index is increasing (Figure 2.C). It is the variable that explains the most of macrofungal diversity, counting approximately $50 \%$ of the total variation.

According to authors [HESSELBARTH \& al. 2019], the Shape Index is calculated as the ratio of patch perimeter and the minimum perimeter. Consequently, it takes values from 1 beyond, rising as the patch shape becomes more complex. Through reducing patch complexity, there are created rectangular patches, characterized by regularity and straight borders [MOSER \& al. 2002].

In order for the macrofungal diversity-shape index complex relationship to be understood, patch shape values variation causes must be known. There are three main groups of factors that influence patch complexity: (i) historical human intervention; (ii) topography; (iii) forest composition [DORNER \& al. 2002; SAURA \& CARBALLAL, 2004]. Shape Index can be used as a direct measure of human interventions, complexity usually decreasing as human activity increased [SAURA \& CARBALLAL, 2004]. On the other side, topographical factors (slope, aspect, terrain rugosity) where found to increase forest patch shape irregularity in Galicia (Spain) [SAURA \& CARBALLAL, 2004]. Also, mountainous forest habitats are characterized by increasing elevation and steep slopes, which hinder human accessibility [SAURA \& CARBALLAL, 2004], which in turn translates through less extracted dead wood and consequently more available wood resources to macrofungi. Thus, increasing shape complexity results in macrofungal diversity increasing, in the up-section of hump-shaped relationship (Figure 2). Irregular shapes and consequently higher Shape Index values can also result from increasing tree diversity [SAURA \& CARBALLAL, 2004]. In our case, the oak-dominated forests from mountainous areas in Neamț County are characterized by higher tree diversity, even if they have high shape index values. In those plots, the macrofungal diversity is lower than in less-rich beech-fir forests from Nemira Mountains. This can explain the second down-section of hump-shaped relationship (Figure 2). Still, this phenomenon might raise a question because high tree diversity is often 
associated with increasing niche variation, because of macrofungal association with particular genera, thus rising fungal diversity [BÎRSAN \& al. 2014]. But forest stands with a higher number of species is less vulnerable to climatic hazards [JACTEL \& al. 2017], represented in the Carpathians by strong winter winds and long snow periods [ANM, 2008]. Therefore, there are more chances for climatic hazards to manifest in mountain beechdominated stands, represented here in the middle of the hump-shaped relationship. This will increase downed dead wood volume in beech-dominated stands, but less in oak-dominated ones, a situation which confirms in our study.

\section{Conclusions}

This is the first study in which diferent types of predictors explain the macrofungal richness found on dead wood in Northeastern Romania. Dead wood quality, elevation and forest fragmentation proved to be key factors in explaining the differences between the total number of fungi in broadleaved-dominated forests. It is the first study that shows the importance of patch shape to macrofungal diversity conservation. Also, dead woodassociated silvicultural practices proved to be of high importance in macrofungal preservation success. As a consequence, it is important to properly manage old forests, keeping high quality downed dead wood, especially in regular forest patches.

\section{Notes on contributors}

Ovidiu COPOT has a PhD in Biology from the Faculty of Biology, "Alexandru Ioan Cuza" University of Iași, Romania and works at "Anastasie Fătu" Botanical Garden of Iaşi. As a young researcher he is focusing on ecological modeling of lignicolous fungal diversity and composition and spatial modeling of all trophic types of macromycetes, in the Northeastern Romania.

Cătălin TĂNASE is a professor at the Faculty of Biology, "Alexandru Ioan Cuza" University in Iași, with a PhD in Biology - Mycology with a special interest in fungal taxonomy and ecology, isolation of biotechnologically important fungal species, phytopathology and biotic interactions. His work is targeting the selection of the fungal species with high potential in the bioremediation of polluted habitats, biotechnological processes and bioconversion.

\section{References}

ABREGO N. \& SALCEDO I. 2011. How does fungal diversity change based on woody debris type? A case study in Northern Spain. Ekologija. 57(3): 109-119. https://doi.org/10.6001/ekologija.v57i3.1916

ABREGO N., BÄSSLER C., CHRISTENSEN M. \& HEILMANN-CLAUSEN J. 2015. Implications of reserve size and forest connectivity for the conservation of wood-inhabiting fungi in Europe. Biological Conservation. 191: 469-477. https://doi.org/10.1016/j.biocon.2015.07.005

ABREGO N., CHRISTENSEN M., BÄSSLER C., AINSWORTH A. M. \& HEILMANN-CLAUSEN J. 2017. Understanding the distribution of wood-inhabiting fungi in European beech reserves from speciesspecific habitat models. Fungal Ecology. 27: 168-174. https://doi.org/10.1016/j.funeco.2016.07.006

ANDRONACHE I., FENSHOLT R., AHAMMER H., CIOBOTARU A. M., PINTILII R. D., PEPTENATU D., DRĂGHICI C. C., DIACONU D. C., RAADULOVIĆ M., PULIGHE G., AZIHOU A. F., TOYI M. S. \& SINSIN B. 2017. Assessment of textural differentiations in forest resources in Romania using fractal analysis. Forests. 8(3): 54. https://doi.org/10.3390/f8030054

Anonymus. 2008. Clima României. Administrația Națională de Meteorologie. București: Edit. Academiei Române, 365 pp.

BAUM S., SIEBER T. N., SCHWARZE F. W. M. R. \& FINK S. 2003. Latent infections of Fomes fomentarius in the xylem of European beech (Fagus sylvatica). Mycological Progress. 2(2): 141-148. https://doi.org/10.1007/s11557-006-0052-5 
BERNICCHIA A. 2005. Fungi Europaei. Polyporaceae s.l. Edit. Candusso, Alassio, Italy, 808 pp.

BÎRSAN C., TĂNASE C., MARDARI C. \& COJOCARIU A. 2014. Diversity and ecological determinants of dead wood fungi in tree natural reserves of broad leaved forests from Suceava county. Journal of Plant Development. 21: 153-160.

BREITENBACH J. \& KRÄNZLIN F. 1986. Champignons de Suisse. Champignons sans lames. Edit. Mykologia, Lucerne. 2: 412 pp.

BRAZEE N. J., LINDNER D. L., D'AMATO A. W., FRAVER S., FORRESTER J. A. \& MLADENOFF D. J. 2014. Disturbance and diversity of wood-inhabiting fungi: effects of canopy gaps and downed woody debris. Biodiversity and Conservation. 23: 2155-2172, https://doi.org/10.1007/s10531-014-0710-x

BRUNET J., FRITZ Ö. \& RICHNAU G. 2010. Biodiversity in European beech forests - a review with recommendations for sustainable forest management. Ecological Bulletins. 53: 77-94.

BURNHAM K. R. \& ANDERSON D. R. 2002. Model selection and multimodel inference - A practical information - theoretic approach. 2nd Edition. Springer, New York, 488 pp. Available from: https://www.springer.com/us/book/9780387953649

ÇOLAK A. H., TOKCAN M. \& KIRCA S. 2010. Dead Wood (Unseen Life on Dead). The Western Blacksea Forestry Research Institute: Istanbul, Turkey, $109 \mathrm{pp}$.

CONRAD O., BECHTEL B., BOCK M., DIETRICH H., FISCHER E., GERLITZ L., WEHBERG J., WICHMANN V. \& BÖHNER J. 2015. System for Automated Geoscientific Analyses (SAGA) v. 2.1.4. Geoscientific Model Development. 8: 1991-2007. https://doi.org/10.5194/gmd-8-1991-2015

COPOȚ O., BALAEȘ T., BÎRSAN C., PETRE C. V., COJOCARIU A. \& TĂNASE C. 2018. Climatic predictors influences VFWD fungal diversity through dominant tree' ecology in beech forests in the North-Eastern Romania. Journal of Plant Development. 25: 119-134. https://doi.org/10.33628/jpd.2018.25.1.119

COURTECUISSE R. \& DUHEM B. 2013. Champignons de France et d'Europe. Edit. Delachaux et Niestlé, 542 pp.

DOMKE G. M., WOODALL C. W., WALTERS B. F. \& SMITH J. E. 2013. From models to measurements: Comparing downed dead wood carbon stock estimates in the U.S. Forest Inventory. PLoS One. 8(3): e59949. https://doi.org/10.1371/journal.pone.0059949

DORNER B., LERTZMAN K. \& FALL J. 2002. Landscape pattern in topographically complex landscapes: issues and techniques for analysis. Landscape Ecology. 17: 729-743, doi: https://doi.org/10.1023/A:1022944019665

DVOŘÁK D., VAŃUTOVÁ M., HOFMEISTER J., BERAN M., HOŃEK J., BĚTÁK J. BUREL J. \& DECKEROVÁ H. 2017. Macrofungal diversity patterns in central European forests affirm the key importance of old-growth forests. Fungal Ecology. 27: 145-154. https://doi.org/10.1016/j.funeco.2016.12.003

GERHARDT E. 1999. Guide Vigot des Champignons, VIGOT, Paris, France, 714 pp.

GOIA I. \& GAFTA D. 2018. Beech versus spruce deadwood as forest microhabitat: does it make any difference to bryophytes? Plant Biosystems - An International Journal Dealing with all Aspects of Plant Biology. 153(2): 187-194. https://doi.org/10.1080/11263504.2018.1448011

HEILMANN-CLAUSEN J. 2001. A gradient analysis of communities of macrofungi and slime moulds on decaying beech logs. Mycological Research. 105(5): 575-596. https://doi.org/10.1017/S0953756201003665

HEILMANN-CLAUSEN J. \& CHRISTENSEN M. 2003. Fungal diversity on decaying beech logs - implications for sustainable forestry. Biodiversity and Conservation. 12: 953-973. https://doi.org/10.1023/A:1022825809503

HEILMANN-CLAUSEN J., AUDE E. \& CHRISTENSEN M. 2005. Cryptogam communities on decaying deciduous wood - does tree species diversity matter? Biodiversity and Conservation. 14: 2061-2078. https://doi.org/10.1007/s10531-004-4284-x

HEILMANN-CLAUSEN J., AUDE E., VAN DORT K., CHRISTENSEN M., PILTAVER A., VEERKAMP M., WALLEYN R., SILLER I., STANDOVÁR T. \& ÒDOR P. 2014. Communities of wood-inhabiting bryophytes and fungi on dead beech logs in Europe - reflecting substrate quality or shaped by climate and forest condition? Journal of Biogeography. 41: 2269-2282. https://doi.org/10.1111/jbi.12388

HESSELBARTH M. H. K., SCIAINI M., WITH K. A., WIEGAND K., NOWOSAD J. 2019. landscapemetrics: an open-source $\mathrm{R}$ tool to calculate landscape metrics. - Ecography. 42: 1648-1657, doi: https://doi.org/10.1111/ecog.04617

JACTEL H., BAUHUS J., BOBERG J., BONAL D., CASTAGNEYROL B., GARDINER B. \& GONZALESOLABARRIA J. R. 2017. Tree diversity drives forest stand resistance to natural disturbances. Current Forestry Reports. 3(3): 223-243. https://doi.org/10.1007/s40725-017-0064-1 
JUUTILAINEN K., MÖNKKÖNEN M., KOTIRANTA H. \& HALME P. 2014. The effects of forest management on wood-inhabiting fungi occupying dead wood of different diameter fractions. Forest Ecology and Management. 313: 283-291. https://doi.org/10.1016/j.foreco.2013.11.019

KEBLI H., BRAIS S., KERNAGHAN G. \& DROUIN P. 2012. Impact of harvesting intensity on wood-inhabiting fungi in boreal aspen forests of Eastern Canada. Forest Ecology and Management. 279: 45-54. https://doi.org/10.1016/j.foreco.2012.05.028

KNORN J., KUEMMERLE T., RADELOFF V., SZABO A., MINDRESCU M., KEETON W. S., ABRUDAN I., GRIFFITHS P., GANCZ V. \& HOSTERT P. 2012. Forest restitution and protected area effectiveness in post-socialist Romania. $\quad$ Biological $\quad$ Conservation. $\quad$ 146: https://doi.org/10.1016/j.biocon.2011.12.020

KUTSEGI G., SILLER I., DIMA B., TAKÁCS K., MERÉNYI Z., VARGA T., TURCSÁNYI G. \& BIDLÓ A. 2015. Drivers of macrofungal species composition in temperate forests, West Hungary: functional groups compared. Fungal Ecology. 17: 69-83. https://doi.org/10.1016/j.funeco.2015.05.009

LOMBARDI F., LASSERRE B., CHIRICI G., TOGNETTI R. \& MARCHETTI M. 2012. Deadwood occurrence and forest structure as indicators of old-growth forest conditions in Mediterranean mountainous ecosystems. Ecoscience. 19(4): 344-355. https://doi.org/10.2980/19-4-3506

MILESCU I., ALEXE A., NICOVESCU H. \& SUCIU P. 1967. Fagul. Edit. Agro-Silvică, București, 581 pp.

MORRISSEY R. C., JENKINS M. A. \& SAUNDERS M. R. 2014. Accumulation and connectivity of coarse woody debris in partial harvest and unmanaged relict forests. PLoS One. 9(11): e113323. https://doi.org/10.1371/journal.pone.0113323

MOSER D., ZECHMEISTER H. G., PLUTZAR C., SAUBERER N., WRBKA T. \& GRABHERR G. 2002. Landscape patch shape complexity as an effective measure for plant species richness in rural landscapes. Landscape Ecology. 17: 657-669. https://doi.org/10.1023/A:1021513729205

PETRITAN A. M., BIRIȘ I. A., MERCE O., TURCU D. O. \& PETRITAN I. C. 2012. Structure and diversity of a natural temperate sessile oak (Quercus petraea L.) - European Beech (Fagus sylvatica L.) forest. Forest Ecology and Management. 280: 140-149. https://doi.org/10.1016/j.foreco.2012.06.007

RUDOLPH S., MACIÁ-VICENTE J. G., LOTZ-WINTER H., SCHLEUNING M. \& PIEPENBRING M. 2018. Temporal variation of fungal diversity in a mosaic landscape in Germany. Studies in Mycology. 89: 95 104. https://doi.org/10.1016/j.simyco.2018.01.001

RUOKOLAINEN A., SHOROHOVA E., PENTTILÄ R., KOTKOVA V. \& KUSHNEVSKAYA H. 2018. A continuum of dead wood with various habitat elements maintains the diversity of wood-inhabiting fungi in an old-growth boreal forest. European Journal of Forest Research. 137(5): 707-718. https://doi.org/10.1007/s10342-018-1135-y

RUNNEL K. \& LÕHMUS A. 2017. Deadwood-rich managed forests provide insights into the old-forest association of wood-inhabiting fungi. Fungal Ecology. 27: 155-167. https://doi.org/10.1016/j.funeco.2016.09.006

RYVARDEN L. 1991. Genera of Polypores. Nomenclature and taxonomy. Dep. of Botany, University of Oslo, 362 pp.

SAAR I., LÓHMUS A. \& PARMASTO E. 2007. Mycobiota of the Poruni old-growth forest (Estonia, Puhatu Nature Reserve). Forestry Studies. 47: 71-86.

SAURA S. \& CARBALLAL P. 2004. Discrimination of native and exotic forest patterns through shape irregularity indices: An analysis in the landscapes of Galicia, Spain. Landscape Ecology. 19: 647-662. https://doi.org/10.1023/B:LAND.0000042905.97437.78

SĂLĂGEANU G. \& SĂLĂGEANU A. 1985. Determinator pentru recunoașterea ciupercilor comestibile, necomestibile și otrăvitoare din România. Edit. Ceres, București, 563 pp.

SCHWARZE F. 1994. Wood rotting fungi: Fomes fomentarius (L.:Fr.) Fr. Mycologist. 8(1): 32-34. https://doi.org/10.1016/S0269-915X(09)80679-4

SIITONEN J., MARTIKAINEN P., PUNTTILA P. \& RAUH J. 2000. Coarse woody debris and stand characteristics in mature managed and old-growth boreal mesic forests in southern Finland. Forest Ecology and Management. 128: 211-225. https://doi.org/10.1016/S0378-1127(99)00148-6

TĂNASE C., BÎRSAN C., CHINAN V. \& COJOCARIU A. 2009. Macromicete din România. Edit. Univ. Al. I. Cuza, Iași, 564 pp.

VAN GILS H., CONTI F., CIASCHETTI G. \& WESTINGA E. 2012. Fine resolution distribution modelling of endemics in Majella National Park, Central Italy. Plant Biosystems. 146: 276-287. https://doi.org/10.1080/11263504.2012.685194 
WOODALL C. W. \& LIKNES G. C. 2008. Climatic regions as an indicator of forest coarse and fine woody debris carbon stocks in the Unites States. Carbon Balance and Management. 3(1): 5. https://doi.org/10.1186/1750-0680-3-5

ŽUPANIC M., MATOŠEVIĆ D., PERNEK M. \& DIMNIĆ D. 2009. Lignicolous fungi on pedunculate oak in lowland forests of Central Croatia. Periodicum Biologorum. 111(4): 397-403.

\section{How to cite this article:}

COPOȚ O. \& TĂNASE C. 2019. Dead wood, forest fragmentation and elevation influences macrofungal diversity on downed coarse woody debris in beech and oak old forest ecosystems from Northeastern Romania. $J$. Plant Develop. 26: 161-172. https://doi.org/10.33628/jpd.2019.26.1.161 